\title{
Typological Characteristics of Japanese
}

\author{
Xiaomu Ren \\ Graduate School of Arts \& Sciences, Department of Linguistics, University of Virginia, \\ Charlottesville, Virginia, United States \\ gdrenxiaomu@sina.com
}

Keywords: Japanese, Typology, Word order, Alignment, Case-marking, Syntax

Abstract: Japanese, as a member of the Japonic language family, primarily spoken in Japan, is an agglutinative East Asian language. This project explores several dominating typological features of Japanese in word order, alignment, case marking and syntactic typology.

\section{Word Order}

\subsection{Order of Subject, Object and Verb}

The order of subject, object and verb in Japanese is SOV. Examples (Nirenburg, Somers \& Wilks 2003) below show that verb is always sentence-final. And the subject is denoted by a nominative marker wa, followed by the direct object indicated by an accusative marker wo. Different case markers will be discussed in next part.

(1) hito-wa yasai-wo tabe-ru

A man-TOP vegetable-ACC eat-PRS

'A man eats vegetable'

(2) ryusan-wa tetsu-wo oka-su

Sulphuric acid-TOP metal-ACC invade-PRS

'Sulphuric acid invades metal'

\subsection{Postpostions}

Japanese is a postpositional language in which the preposition always follows its complement. There are three kinds of Japanese postpositions: $e, n i$ and de. They mainly serve the functions of LOCATIVE (ni, de), DATIVE/GOAL/ DIRECTION $(n i, e)$ and INSTRUMENT (de). Example (Vinka 2013) are given as below, which show that these prepositions are attached to their complements very closely. In this term, sometimes they are treated as the case-markers as well. The preposition $n i$ conveys the meanings of locative 'in/at/on XXX(place)' in (1b), (1c) and (1d) and dative 'to sb./sth' in (4a). De contains the meaning of locative as well in (1a) and instrument 'by/with sth.' in (5). The preposition $e$ in (4b) and (4c) denotes the direction which is equal to the English preposition 'to/toward'.

(3) LOCATIVE (ni, de):

a. Watashi-wa gakkoo-de eigo-o narat-ta. 
I-TOP school-in/LOC English-ACC learn-PST

'I learned English in School'

b. Maiban, boku-ga Tsubohachi-de biiru-o nomu.

Every night, I-NOM Tsubohachi-at/LOC beer-ACC drink

'I drink beer at the pub called Tsubohachi every night.'

c. Watashi-wa Gifu-shi-ni sunde-iru.

I -TOP Gifu City-in/LOC live-PRS

'I live in Gifu City.'

d. Boku-wa ano isu-ni suwari-tai.

I-TOP that chair-on/LOC sit want-PRS

'I want to sit on that chair.'

(4) DATIVE/GOAL/DIRECTION (ni, e):

a. Taroo-ga Hanako-ni hana-o age-ta.

Taroo-NOM Hanako-to/DAT flower-ACC give-PST

'Taroo gave Hanako a flower.'

b. Boku-ga Kyoto-e it-ta.

I NOM Kyoto-to go-PST

'I went to/toward Kyoto'

(5) INSTRUMENT (de):

a. Boku-wa jitensha-de gakkoo-e it-ta.

I-TOP bicycle-by/INS school-to go-PST

'I went to school by bicycle.'

b. Watashi-wa enpitsu-de tegami-o kai-ta.

I-TOP pencil-with/INS letter-ACC write-PST

'I wrote a letter with a pencil.'

c. Nihonjin-wa hashi-de tabe-ru.

Japanese people-TOP chopsticks-with/INS eat-PRS

'Japanese people eat with chopsticks.'

\subsection{Order of Adjective and Noun}

The order of adjective and noun in NP is Adjective-Noun that the adjective precedes the noun that it is modifying. Example (Michelsen 2010) are given in (6) and (7) reveal that there are two categories of adjectives: $i$-adjective and $n a$-adjective. The difference is that the $i$-adjective ends with $i$, while the na-adjective takes na before the noun it is modifying. So na gets dropped when the na-adjective is in the predication. For each category, adjectives can directly modify the noun following it.

(6) a. furui mono

Old thing

'Old thing'

b. ookii honya

Big bookstore

'Big bookstore'

(7) a. Kireina hito

Pretty person

'Pretty person'

b. yumeina hito

Famous person 
'Famous person'

On the other hand, when the adjective is in the predication--example (8) and (9), the order of adjective and noun is Noun-Adjective, without the be-verb/linking-verb. The morpheme desu following the adjectives indicates the predication. It is added to $i$-adjective without changing the form of $i$-adjective, while to a na-adjective should have the na get dropped.

(8) a. Watashi-no kuruma-wa ookii-desu

My-GEN car-TOP big

'My car is big'

b. Ano kuruma-wa hayai-desu

That car fast

'That car is fast'

(9) a. Yumei-na gakko-desu

Famous school

'It is a famous school'

b. Kono gakko-wa yumei-desu

This school-TOP famous

'This school is famous'

\subsection{Order of Possessor and Possessed Noun}

Additionally, according to Universal 2 of Greenberg and the data have been collected, the order of genitive and governing noun is Genitive-Noun, that the possessor always precedes the governing/possessed noun. The genitive in Japanese is denoted by the marker no on the possessor noun preceding the possessed noun, for examples (Kishimoto 2013) for (10) and (11) and (Ura 1996) for (12):

(10) sensei-no me teacher-GEN eye

Lit. Teacher's eye

'Teacher's attention'

(11) gakusei-no megane

Student-GEN glasses

Lit. Student's glasses

'Student's expectations'

(12) Mary-no kami-ga naga-i.

Mary-GEN hair-NOM long-be

'Mary’s hair is long.'

\subsection{Order of Numeral, Demonstrative and Noun}

Similar to Chinese and Korean, Japanese numerals cannot quantify nouns by themselves. The counter word, which is various depending on nouns, has to follow the numeral. There are two kinds of order to express the number. One is Numeral-Noun, shown in (13), the genitive case marker no is added to the numeral and the counter to express the meaning 'two of....'. The other is Noun-Numeral, given in (14), which is without the markers. Examples are from Bender\&Siegel (2004).

(13) a. ni-hiki-no neko
Two-NumC-GEN cat

'Two cats'

b. ni-hiki-no neko-wo ka-u 
Two-NumC-GEN cat-TOP raise-PRS

'(I) raise two cat'

(14) a. neko ni-hiki

Cat two-NumC

'Two cats'

b. neko-wa ni-hiki ie-de

Cat-TOP two-NumC house-LOC

'I raise two cats in (my) house'

Furthermore, according to Greenberg' Universal 18 and the data set, in Japanese, if the descriptive adjective always precedes the noun, then the numeral and demonstrative should precede the noun as well.

(15) kono hon

this/my-DEM book

(16) sono hon

that/your-DEM book

\section{Alignment and Case-Marking}

\subsection{Alignment in S1, A2 and P3 Role}

Japanese has a nominative-accusative alignment by treating the $S$ argument of an intransitive verb like the $A$ argument of a transitive verb, with $\mathrm{P}$ argument distinct ( $\mathrm{S}=\mathrm{A}$, $\mathrm{P}$ separate). Because of the lack of verb-agreement, Japanese applies the case-markers to indicate the roles of the sentence elements. Examples below (Fukuda 2007) manifest that for all kinds of grammatical person and number, the nominative position (subject) of both transitive and intransitive verb is always marked by ga (or wa under certain circumstances to indicate TOPIC), while the accusative position (object) is distinct by the marker $o$.

(17) kodomo-ga aruk-ta

Child-NOM walk-PST

'Child walked'

(18) gakusei-ga geragerato waraw-ta

Students-NOM loudly laugh-PST

'Students laughed loudly'

(19) gakusei-ga yama-o nobor-ta

Student-NOM mountain-ACC climb-PST

'The student climbed the mountain'

(20) Boku-ga atsui-yakan-o ukkari sawar-ta

I-NOM hot-kettle-ACC by.mistake touch-PST

'I touched the hot kettle accidentally'

(21) sukaato-ga yuka-o sawar-ta

Skirt-NOM floor-ACC touch-PST

'The skirt touched the floor'

(22) Ken-ga Taro-ni aw/bustukar/dekuwas-ta

Ken-NOM Taro-DAT meet/run into/come-PST

\footnotetext{
${ }^{1} \mathrm{~S}$ : Argument of intransitive verb

${ }^{2}$ A: Argument of transitive verb behaving like a canonical agent

${ }^{3} \mathrm{P}$ : Argument of transitive verb behaving like canonical patient
} 
'Ken met/ran into/came across Taro'

(23) Kare-wa shefu desu

He-TOP chef (ARTICLE)

'He is a chef'

(24) Anatachi-wa gakusei desuka?

You-TOP student (ARTICLE)

'Are you student?'

So for both pronouns and nouns of all grammatical person and number, the forms of alignment in Japanese is listed in Table 1:

Table.1: Case-markers for S, A and P role

\begin{tabular}{llll}
\hline Grammatical person\&number & $\mathrm{S}$ & $\mathrm{A}$ & $\mathrm{P}$ \\
\hline $1^{\text {st }}$ sg\&pl & $g a / w a$ & $g a / w a$ & $o$ \\
$2^{\text {nd }}$ sg\&pl & $g a / w a$ & $g a / w a$ & $o$ \\
$3^{\text {rd }}$ sg\&pl & $g a / w a$ & $g a / w a$ & $o$ \\
\hline
\end{tabular}

\subsection{Japanese Case-marking}

Japanese is an almost purely dependent-marking language without any kinds of head-marking. So the verb-agreement is not involved in Japanese, namely, verbs do not have different forms to indicate grammatical person, number or gender. The same form of a verb is employed no matter what properties its arguments have.

As a dependent-marking language, case-marking system exists. Japanese nouns do not have plurality. They work both as singular and as plural without changing the forms. Examples given below present the different case markers (nominative, topic, accusative, dative, locative, lative, ablative and instrument) are attached to nouns to show their roles or cases in the sentence.

(25) boku-ga tomodati-ni hana-o age-ta

I-NOM friend-DAT flower-ACC give-PST

'I gave flowers to my friend' (Zwart 2004)

(26) Tanaka-no yasashii-tomodachi-ga ki-ta

Tanaka-GEN nice-friend-NOM come-PST

‘Tanaka’s nice friend came’ (Bender\&Siegel 2004)

(27) toukyou-kara ki-ta

Tokyo-ABL come-PST

'(Someone) came from Tokyo'

(28) kono kuruma-wa arukouru-de dare ugokemasu

This-DEM car-TOP alcohol-INS only move

'This car runs only on alcohol'

(29) watashi-wa nohon-e ichido it-ta

I-TOP Japan-Lative once go-PST

'I went Japan (only) once'

(30) kono hoteru-ni/de hooru-ga aru

This-DEM hotel-LOC hall-NOM be- $3^{\text {rd }}$ SG.

'There is a hall in this hotel.' (Ohtani 2013)

So according to the data, the paradigm of the word toukyou 'Tokyo' is presented in the following table 2: 
Table 2: Case markers for 'Tokyo'

\begin{tabular}{ll}
\hline Case & Forms of 'Tokyo' \\
\hline Nominative (NOM) & toukyou-ga \\
Topic (TOP) & toukyou-wa \\
Accusative (ACC) & toukyou-(w)o \\
Dative (DAT) & toukyou-ni \\
Locative (LOC) & toukyou-ni/de \\
Lative & toukyou-e \\
Ablative (ABL) & toukyou-kara \\
Instrument (INS) & toukyou-de \\
\hline
\end{tabular}

\section{Syntactic Typology}

\subsection{Passives}

Japanese passives have the valency-changing operation. The original subject could be omitted in a prototypical passive sentence. But for most cases, Japanese passives switch the position of the original subject and object and then change the accusative marker $(w) o$ of the original subject to the dative marker ni. Then the original subject becomes the dative agent NPs as the adjuncts. The examples (Toyota 2011) of basic passives in Japanese are shown below:
(31) a. George-ga gitaa-wo hik-u
George-NOM guitar-ACC play-PRS
'George plays the guitar'
b. Gitaa-ga (George-ni) hik-are-ru
Guitar-NOM George-DAT play-PASS-PRS
'The guitar is played (by George)'
(32) a. Keisatsu-ga Ken-wo
Police-NOM Ken-ACC
tsukamae-ta
'The police caught Ken'
b. Ken-ga (Keisatsu-ni) tsukmae-rare-ta
Ken-NOM police-DAT catch-PASS-PST

'Ken was caught (by the police)'

Seen from the examples above, Japanese passives employ the verb affixes as the morphological devices. The verb is marked morphologically. The suffix indicating the passive is attached to the verb. If a verb ends in a consonant, then adding the suffix are or aremasu (polite form), such as the verb hik 'play' in example (31a), applying the suffix are to get the passive form /hik-are/ 'be played'. Otherwise, if a verb ends in a vowel, such as the verb tsukamae 'catch' in example (32b), attaching the suffix rare or raremasu (polite form) to obtain the passive form tsukamae-rare 'be caught'.

There is no special particles employed to indicate passives. But the case markers ga and $n i$ are involved to understand the construction of passives. The nominative position is always marked by $g a$. When the passives are built on transitive clauses, on the one hand, the original direct object (O) is promoted to the sentence-initial nominative position as a subject (A) marked by ga. On the other hand, the original subject is switched to the place in which follows its new subject and shown by the dative case marker ni which means 'by XXX..' in passives. Comparing the examples (31) and (32), the noun at the nominative position is always marked by ga. In (31a) and (32a), 'guitar' and 'Ken' are at the accusative position marked by wo. In the passives shown by (31b) and (32b), 'guitar' and 'Ken' are promoted to the nominative position, while the original objects 'George' and 'police' are switched to the position following the nominatives and marked by the dative case marker ni to indicate the meaning 'by George' and 'by police'. 
Beyond the basic passives, Japanese has a special kind of passives called indirect passives which do not have the corresponding active forms and are allowed to be built on intransitive clauses and stative verbs. And the devices of morphological marker on verbs is employed as well to indicate indirect passives. Indirect passives sometimes are called pseudo-passives because which are not the real passives. Indirect passives are used when the action, which was done on the subject by someone, is out of the subject's control, namely, to express an event which is unfortunate or someone has been suffered from something. Several examples (Kubo 1992) of indirect passives are given below:

(33) Paul-wa John-ni shin-are-ta

Paul-NOM John-DAT die-PASS-PST

Lit. 'Paul was died by John'

'Paul was adversely affected by John's death'

(34) Ken-wa ame-ni hu-rare-ta

Ken-NOM rain-DAT descend-PASS-PST

'Ken was rained on'

(35) Ken-wa Naomi-ni sinkoosyuukyoo-o hajime-rare-ta

Ken-NOM Naomi-DAT new religion-ACC begin-PASS-PST

Lit. 'Ken was joined a new cult by Naomi'

'Ken experienced Naomi's joining a new cult'

Shown by the examples above, indirect passives also apply verb affixes and indicate the agent phrase with the dative marker ni. In example (33) and (34), intransitive clauses can be built as passives. Then, example (35) presents that the passives can be built on stative verbs as well. However, as for any type of verbs, phonological rules of applying the morphological markers---affixes are and rare on verbs are the same as what the direct passives follow.

There are two differences between the indirect passives and the basic passives. Firstly, indirect passives do not have the corresponding active ones. Because indirect passives are supposed to express the passive feelings. Secondly, the nominative position in indirect passives is marked by the topic marker wa.

So the consequences of the interpretation of the case markers in the indirect passives could be confusing that an actor is interpreted as Accusative and a sufferer as Nominative in the same sentence. However, under this circumstance, the sufferer takes the semantic role as an experiencer which is also supposed to be in a nominative position. And because of the East Asian culture background, the expressions in Japanese are supposed to be indirect and obscure.

\subsection{Causatives}

Japanese causatives are lexical and morphological. The periphrastic causatives are not applicable. And same as the passives, Japanese causatives apply the valency-changing strategy by introducing the new argument---the causer.

As for the lexical causatives, there are two subtypes. One is the zero-derived lexical causatives, in which the verbs do not change their forms but do contain the causative meaning, which is shown in (36). Another type of the lexical causatives is that some verbs in Japanese already consist of the morpheme sase, namely, the causative morpheme sase is a part of the verbs, but not regarded as an affix. The example (37) shows that the stem of the verb 'rot' is kusarase.
(36) Taroo-ga hune-o sizume- $\varnothing$-ta
Taro-NOM boat-ACC sink-CAUS-PST
Lit. 'Taro sank the boat'
'Taro makes the boat sink' (Harley 1995) 
(37) Taroo-ga yasai-o kusar-(s)ase-ta

Taro-NOM vegetable-ACC rot-CAUS-PST

'Taro caused the vegetable to rot' (Harley 1995)

However, the most common way to obtain the causatives is morphological by attaching the affix sase to verbs, for example (Harley 1995):

(38) Taroo-ga Hanako-ni hon-o yon-(s)ase-ta

Taro-NOM Hanako-DAT book-ACC read-CAUS-PST

Lit. 'Taro made the book read by Hanako'

'Taro made Hanako read the book'

(39) Taroo-ga Ziroo-ni Kazuo-o home-sase-ta

Taro-NOM Ziro-DAT Kazuo-ACC praise-CAUS-PST

Lit. 'Taro made Kazuo praised by Ziro'

'Taro made Ziro praise Kazuo'

Furthermore, the data show that the lexical causatives are able to be constructed on ditransitive verbs, while the morphological causatives can be built on both intransitive and transitive verbs. Because in Japanese, the ditransitive verbs are in the form of lexical causatives. Example (40a) and (40b) present the lexical causatives with the Japanese ditransitive verbs kiseru 'put on' and watasi 'pass', while in example (41) and (42), the morphological causatives are indicated by the causative morpheme (s)ase in the transitive and intransitive verbs.

(40) Ditransitive Lexical Causatives:

$\begin{array}{llll}\text { a. Hanako-ga } & \text { Taroo-ni } & \text { yoohuku-o } & \text { kiseru } \\ \text { Hanako-NOM } & \text { Taro-DAT } & \text { clothes-ACC } & \text { put-on }\end{array}$

'Hanako puts the clothes on Taroo'

b. John-ga hanataba-o Mary-ni watasi-ta

John-NOM bouquet-ACC Mary-DAT pass-PST

'John passed a bouquet to Mary'

(41) Intransitive Lexical Causatives(Harley 1995):

$\begin{array}{lll}\text { a. Calvin-ga } & \text { Hobbes-o } & \text { ik-ase-ta } \\ \text { Calvin-NOM } & \text { Hobbes-ACC } & \text { go-CAUS-PST }\end{array}$

'Calvin made Hobbes go'

(42) Transitive Lexical Causatives (Harley 1995):
a. Calvin-ga
Hobbes-ni
Calvin-NOM Hobbes-DAT
pizza-o
tabe-sase-ta

'Calvin made Hobbes eat pizza'

\section{References}

[1] Nirenburg.S, Somers.H, Wilks.Y, (Eds.) (2003) Reading in Machine Translation. The MIT press Cambridge, Massachusetts London, England

[2] Vinka. M (2013) The Syntax of Three Japanese Postpositions. Lund University, Dept. of Linguistics Working Papers 40 (1993), 229-250

[3] Michelsen.R (2010) A beginners guide to understanding Japanese word order, noun modifiers and relative clauses. Public document.

[4] Kishimoto.H (2013) Covert possessor raising in Japanese. Natural Language \& Linguistic Theory Volume 31, Issue 1, pp 161-205

[5] Fukuda.S (2007) Object Case and Event Type: Accusative-Dative Object Case Alternation in Japanese. Berkeley Linguistics Society and Linguistic Society of American, BLS 33, NO 1.

[6] Zwart. J.W (2004) Rethinking Head vs. Dependent Marking Grammar, Nederlands/ATW, Groningen, TIN-dag, February 7

[7] Bender. E.M, Siegel. M (2004) Head-Initial Constructions in Japanese. Proceedings of the 11th International Conference on Head-Driven Phrase Structure Grammar, CSLI Publications, pages 244-260 
[8] Ohtani. A (2013) Locative Postpositions and Conceptual Structure in Japanese. Anthology: Y13-1039; Volume: Proceedings of the 27th Pacific Asia Conference on Language

[9] Toyota. J. (2011) The Grammatical Voice in Japanese: A Typological Perspective. Cambridge Scholars Publishing [10] Kubo (1992) Japanese Passives. MIT 24.953: Argument Structure

[11] Harley, H. (1995) Case Bizarre: The Structure of Japanese Causatives. In Proceedings of the 1995 annual conference of the Canadian Linguistic Association, ed. P. Koskinen: 225-235.

[12] Erlewine. Y. M \& Gould. I, (2016) Unifying Japanese Relative Clauses: Copy-Chains \& Context-Sensitivity. Glossa: a journal of general linguistics 1(1): 51.1-40

[13] Tanaka. M (2010) Head-Internal Relative Clauses in Japanese: Movement vs. Agree. Master thesis, Linguistics: The Study of the Language Faculty, Utrecht Institute of Linguistics OTS Utrecht University

[14] Kuno, Susumu 1973. The Structure of the Japanese Language Cambridge, MA: MIT Press

[15] Inada, Shunichiro (2009). On the “AMOUNT" Relativization and Its Relatives. Linguistic Research 25:85-102

[16] Mitsugi, S., MacWhinney, B., \& Shirai, Y. (2010). Cue-Based Processing of Relative Clauses in L2 Japanese. In M. T. Prior, Y. Watanabe, and S.-K. Lee (Eds.), Selected Proceedings of the 2008 Second Language Research Forum: Exploring SLA Perspectives, Positions, and Practices (pp. 123-138). Somerville, Mass.: Cascadilla Proceedings Project.

[17] Ishizuka. T (2005) Processing Relative Clauses in Japanese. UCLA Working Papers in Linguistics, no.13, December 2005 Papers in Psycholinguistics 2, Okabe and Nielsen (eds.)

[18] Matsumoto. Y (1997). Noun-Modifying Constructions in Japanese: A Frame Semantic Approach. John Benjamins Publishing Co, Philadelphia, USA.

[19] Tsujimura. N (2007) An Introduction to Japanese Linguistics. Blackwell Publishing

[20] Ura, Hiroyuki. 1996. Multiple feature-checking: A theory of grammatical function splitting. Doctoral Dissertation, MIT.

[21] Bender. E. M., Siegel. M (2004) Implementing the Syntax of Japanese Numeral Classifiers. International Conference on Natural Language Processing IJCNLP 2004: Natural Language Processing - IJCNLP pp 626-635 